\title{
Corporate Governance and Organisational Survival in Manufacturing Firms in Port Harcourt
}

\author{
Williams O. Olori PhD \\ Department of Management, Faculty of Management Sciences, University of Port Harcourt, Rivers State, \\ Nigeria \\ Shaibu Jemilla Ladi \\ Department of Management, Faculty of Management Sciences, University of Port Harcourt, Rivers State, \\ Nigeria
}

\begin{abstract}
This study examined the correlation between corporate governance and organisational survival in manufacturing firms in Port Harcourt. It sought to proffer solutions to survival challenges experienced by firms, through an indepth application of the concept of corporate governance. Data was collected from 198 management staff through the use of questionnaire. The data was analysed by the use of descriptive statistics and Spearman's Rank Order Correlation Coefficient. The result revealed a positive relationship between the dimensions of corporate governance board independence and board supervision, and the measures of organisational survival (Innovation and adaptability. Also, the result showed that organisational structure significantly moderates the relationship between corporate governance and organisation survival. The study concludes that board independence has a significant and positive correlation with organisational survival in manufacturing firms. Based on the findings it was recommended that manufacturing firms should ensure that their boards are independent and board supervision should be enthroned to enhance efficiency and corporate survival.
\end{abstract}

Keywords: Corporate Governance, Organisational Survival, Board independence, Board size, Innovation, Adaptability

DOI: $10.7176 / \mathrm{JRDM} / 64-06$

Publication date: April $30^{\text {th }} 2020$

\section{Introduction}

Organisations like other social systems are networks of component parts that makes up the entire system. For such a system to survive it must have the capacity to adjust, operate from year to year and grow, irrespective of its line of business (Khanka 2008). In periods of economic prosperity or stable business environment, most businesses ignore the consequences of failure. (Anyanwu \& Agwor, 2015). This point sees every organisation strategizing on how to remain in business as a precursor to growth. Most business failures are, nonetheless, not the result of unfavourable external environmental manifestations, but a failure of leadership to align their internal operations with the requirements of the dynamic external environment. Survival therefore requires that managers continuously implement the outcome of organisational learning to avoid the effect of environmental variations that could be inimical to sustainability (Matai, 2011). It has been argued that a major determinant of the wellbeing and long term economic survival of an organisation is corporate governance (Sarbah \& Xiao, 2015) and that failure in governance systems are a major cause of collapse of many organisations around the world (Duke \& Kankpang, 2011). Corporate governance requires organisational stakeholders to always observe the principles, rules and regulations that guide the decisions and actions of their company (Oyebode, 2009). Emphasis on corporate governance results from the differences in interest between the major parties in an organisation, that is managers and owners, which arises from the difficulty and almost impossibility of business owners to personally manage their businesses because of the enormous size, relentless growth and complexity of modem business operations and environment. Hence, corporate governance creates the environment and culture within which an organisation pursues its legitimate goals for the benefit all stakeholders - owners, managers and employees, government and society (Omolade \& Tony, 2014).

Improvement in corporate governance practices is generally believed to be among the crucial factors in solidifying the foundation for the success of organisations as effective board independence, board supervision, and board size are seen as crucial for enhancing economic activities particularly in developing and emerging markets and results in survival and longevity of the organisation (Dharwardkar, George \& Brandes, 2000). This is because at various degrees of agency interactions, market situations are aimed at reducing imperfections in information as well as enhance appropriate monitoring of managers to facilitate efficient investment decisions, and this explains why corporate governance is so central to corporate performance (Omolade \& Tony, 2014). Both empirical and theoretical studies abound employing various variables as means of proffering solutions to the challenges of survival among business enterprises. However, there is a dearth of studies on how corporate governance correlates with organisational survival with particular emphasis on manufacturing firms in Nigerian. 
In light of this, this work seeks to fill this void that has been observed by examining the impact of corporate governance on organisational survival in the Nigerian manufacturing sector, specifically in Port Harcourt, Rivers State.

\section{Statement of the Problem}

Achieving corporate goals and objectives while striving to accomplish long-term success is the ultimate desire of every organisation. However, increased globalization has widened the competing elements that Nigerian manufacturing firms have to contend with. A general slump in economic activities, unfavourable balance of trade and exchange rate with the concomitant high cost of imported raw materials are all contributing factors to the struggles of manufacturing firms to maintain success. Survival is an indicator of a firm's understanding of, and ability to satisfy, the needs of its stakeholders. The survival of many manufacturing firms in Nigeria is continuously threatened because of frequent changes in the business environment. In 2016, about 272 manufacturing firms were shut down while others scaled down operations, workforce and remuneration because of difficulties ranging from unfavourable exchange rate, poor infrastructure, and high cost of raw materials and banking charges (Nigerian Manufacturers Laments, 2017). For instance, Erisco Foods Limited shut down its four billion naira tomato paste processing plant in Oregun, Lagos, sacked over 1,500 workers, while Dag Motorcycles Industries Nigerian limited - assemblers of Bajaj motorcycles and tricycles — reduced production by $40 \%$ and laid off staff (Alli, 2017). These survival challenges are, however, not due solely to adverse macroeconomic environment, but may be accounted for by failure to appropriately manage the operations of the organisations. Omolade and Tony (2014) opined that a major strategic step for firms facing difficulties is the appreciation and proper institution of corporate governance. However, there is scanty empirical evidence on how organisational survival is affected by corporate governance in the Nigerian context, while the few available studies have only focused on the financial sector with little or no attention given to manufacturing firms (Odiwo. Chukwuma \& Kifordu, 2016). In view of the foregoing, this research seeks to examine and establish the degree to which board independence, board size, and board supervision relate with innovation and adaptability of manufacturing firms in Port Harcourt.

\section{Research Hypotheses}

1. There is no significant relationship between board independence and innovation.

2. There is no significant relationship between board independence and adaptability.

3. There is no significant relationship between board supervision and innovation.

4. There is no significant relationship between board supervision and adaptability.

\section{Literature Review}

The review of extant literature shows that several theories explain corporate governance and organisational survival. The baseline theory upon which this study is predicated is the stewardship theory and resource dependency theory (Pfeffer \& Salancik, 1978; Donaldson, 1990). The stewardship theory, which was developed by Donaldson (1990), states that managers are servant or stewards whose actions mirrors the desires and interests of the owners of the organisation. Thus, the interests of managers and the board of directors are aligned with those of shareholders; with managers' actions being inherently motivated to be in ways that best serve the achievement of organisational goals, while reaping intangible benefits like the prospects for personal growth and accomplishment (Chambers, Harvey, Mannion, Bond, \& Marshall, 2013). This theory takes a rather divergent view from the agency theory which sees managers as self-centred, having interests that conflicts with those of owners, and must consequently be monitored and controlled to ensure conformity to owners' interests. It emphasized on the importance of congruence in the aspirations of individual members and various units in the organisation. The stewardship theory therefore explains that the job of the board of directors is to deliver an environment and make policies that are supportive to Chief Executive Officer (CEO) and the management team in running the affairs of their organisation. This theory suggests that boards that has many executive members are better equipped with the competence of managing corporate resources sensibly and that, on the basis of trust, greater autonomy should be given to managers as this will help reduce the cost associated with watching their behaviours to ensure compliance to the common good (Bathula, 2008). Arguing in similar manner, Daily, Dalton, and Cannella (2003) averred that as managers and directors strive to create and defend their prestige while managing their organisations, it is in their interest to make appropriate strategic decisions that leads to improved overall performance of the firm, which also influences the perception of the capability of the management team. The stewardship theory has significant consequence on the management of a firm as it discloses the imperatives for the role of managers' to be explicitly defined and supported by adequate authority, worth and power (Abid, Khan, Rafiq \& Ahmed, 2014). 


\section{Concept of Corporate Governance}

Dabor, Isiavwe and Ajagbe (2015) stated that corporate governance represents a structural arrangement through which corporations and businesses alike are administered and directed to increase the return on shareholders' investment and realize the prospects of other entities that have a stake in the organisation. This structure is put in place in a bid to create a clear work atmosphere that can better the firm's competitive strength and eventual growth. Corporate governance applies to both private and public enterprises, including principles, guidelines and acceptable corporate practices, which collectively oversee the association, in any capitalist market, between business executives and industrialists (corporate insiders) on one hand, and outside investors of resources in business organisations, on the other (OECD, 2001).Thus, it is a system through which investors influence management to behave and act in the interest of the investors, creating a level of assurance that is indispensable for effective functioning of capital markets (Enofe \& Isiavwe. 2012). However, improper corporate conducts, fraud and mismanagement of funds and resources by board members and managers are not uncommon in organisations nowadays as failed corporate governance mechanisms consistently leads to failure of organisations (Enofe \& Isiavwe, 2012). Business failures have brought to the fore of corporate discourse, the importance of corporate governance in organisational survival. In essence, the effectiveness of the structural arrangement in place tends to squarely drive organisational activities from where is it to where it intends to be; thereby engendering the achievement of predetermined objectives. Some dimensions of corporate governance as proposed by Chancharat and Chancharat (2013) namely, board supervision and independence were adopted for this study.

\section{Board Independence}

The independence of the board of directors makes a significant and interesting discourse in the governance of a company; and this has been universally recognized as there is no mutual or shared agreement concerning the meaning of independence within the context of corporate governance. The differences between executive and non- executive directors can be viewed from three aspects namely the agency perspective, the level of accountability to the headship of the board, and independence leadership structure as a measure of board sovereignty (Lamberto \& Rath, 2008). Based on agency standpoint, Lamberto and Rath (2008) further averred that a prevalence of high proportion of independent directors on the board, diminishes the possibility of the CEO and executive directors carrying out actions that do not further the interest of shareholders. Pass (2004) maintained that the benefits associated with the autonomous and unbiased contributions of non-executive directors may be lost with the non-existence of sovereign directors. Again, the firm benefits from the considerable contributions of non-executive directors in terms of outward business know how to the firm, and often identify threats and opportunities for the firm which otherwise would have gone undetected or ignored by the firm's inside directors who are stereotypically absorbed in the day-to-day operation of the firm. The outcomes of current studies concerning the properties of the proportion of directors who are not members of the executive team on the survival and performance of organisations show mixed results. Two, chairman or chairperson is accountable and answerable to the headship of the board, in pursuit of the well-organized coordination and performance of the functions of the board and for the conference of all directors vis-a-vis matters arising at board conferences (Weir \& Laing, 2001), as it is anticipated that a firm with the existence of a sovereign chairman or chairperson is more probable to follow the benefits of the shareholders and effectively monitor the decisions of managers (Weir \& Laing, 2001). This tends to show that the external executive chairman or chairperson improves the operational routine and survival of the corporation.

In contrast to this, it is expected of the executive chairman or chairperson to have superior information about the organisation as well as its industry and exhibit superior pledge and organisational commitment to the firm than is typical of a non-executive or external chairman or chairperson (Boyd, 1995). Three, the use of independent leadership structure is the measure of the sovereignty of the board. CEO duality describes the governance structure in which the same individual functions as an organisation's CEO and the board chair at the same time while the situation where different persons serve in each of these positions is described as independent leadership structure (Boyd, 1995). However, contradictory views exist in respect to advantages and disadvantages associated with each of these leadership structures. Advocates of the autonomous or sovereign structure contend that dual CEO leadership tend to establish clear lines of interest and gravely impinge or reduces the board's capability to undertake its control duties (Rechner \& Dalton, 1991).

\section{Board Supervision}

Previous works on supervision within the context of corporate governance tend to indicate that directors and managers with professional know-how are better at the management of overseeing the performance of the firm (Rechner \& Dalton, 1991). Adams and Mebran (2003) suggest that highly competent directors do well in performing their firm-specific activities because of their management know-how. Boyd (1995) that overseeing 
the management competencies of a board to sufficiently monitor the enormous and intricate affairs of an organisation is a function of the knowledge, skills, resource vision, and experience of its directors. Pass (2004) refer to the abilities of directors - in terms of legitimacy experience, and abilities - to connect the organisation to major stakeholders or other significant parties. Weir and Laing (2001), states that the act of managing and overseeing performance results of directors' competencies in accounting and financial matters is better as it enhances organisational agility. Organisations whose board comprised of members who are highly knowledgeable in finance analyse and present operational and financial information in an objective and straightforward manner (Pass, 2004). Therefore, board and audit committee members with high management capabilities are equally superior fat disclosing impartial and appropriate company information. Therefore, directors with high academic qualifications are more generally knowledgeable just as those who hold more than one job have greater exposure to rubrics of business operations. As noted by Maher and Andersson (1999), continuous educational programmes and trainings equally have high capabilities in business operations and can thus provide better information about the firm's activities.

Disclosing information in a transparent manner affords all stakeholders the access to the reasons that inform management's decisions as well as the ability to objectively evaluate management performance; and this promotes stronger relationship between managers and other stakeholders. Donaldson (1990) opined that within the context of stewardship theory, compensation shows the actions of managers to be in alignment with the interests of other shareholders. A majority of the literature highlights the critical position of compensation in shaping the actions of managers. Additionally, the role of transparency in structural arrangement in the governance of an organisation cannot be overstated, however while the importance of the board of directors in a firm's structural arrangement has been stressed in previous studies, only a handful of studies attempted an examination of how directors' capabilities relate with firm's transparency in addressing shareholders' concerns (Recbner\& Dalton, 1991).

\section{Concept of Organisational Survival}

Organisational survival is a concept that has gained immense popularity among management scholars and practitioners alike as it has gradually becomes an essential element in assessing an organisation's growth, its profitability, its capacity to add value to society, as well as a tool for measuring its immediate and future prospect for survival. Firms whose manufacturing systems are survival-focused are driven by the desire to differentiate their products and services in the ever competitive marketplace (Setia \& Soni, 2013). There is no generally accepted definition of organisational survival due in part to the myriad of cognate terms used to describe it. However, there seem to be a convergence of opinion about survival describing it as an organisation's capacity to achieve current objectives without threatening future prospects. Roper (2012), took a business perspective by defining survival as a company's ability to accomplish its corporate objectives and increase longterm value for shareholders by incorporating economic, environmental and social opportunities into its business strategies. Survival strategies increases an organisation's awareness of its environment including its external environment and proffer solutions to challenges (Setia \& Soni, 2013). Collis (1996), outlined the regular and common description of organisational survival as; keep the business going, future proofing, and achieving success today without compromising the needs of the future. Organisational survival explain the effectiveness of a firm, both in terms of maintaining human or societal welfare and preservation of the ecosystem, as it seeks the attainment of its goals (Sharma \& Ruud, 2003).

This study defines organisational survival as the strength of an organisation to realise it profitability objectives in the present and still meet the expectations of its constituents so as to remain in business in the long run. Survival has gained considerable importance in the manufacturing sector in Nigeria, and is now being projected as a major indicator of success in a sector that is struggling to avoid extinction. Setia and Soni (2013), concluded that effective manufacturing firm employs descriptive metrics, advanced decision-making models, and public policy for implementation, evaluation, and feedback. With the increased globalization and Nigerian manufacturing firms' continuous dependence on importation of raw materials and machines, survival strategies will be paramount for manufacturing organisations in the coming decades.

\section{Innovation}

Innovation according to Baregheh, Rowley and Sambrook (2009) is a "multistage process whereby organisations transform ideas into new/improved products, services or processes in other to advance, compete and differentiate themselves successfully in their market place". Innovation is a key strategy that firms use in reacting and preempting threats and opportunities in an environment which tend to be full of uncertainties (Darroch, 2005). Prajogo and Sohal (2001) noted that innovation is a requisite for an organisations' long-term performance and survival that establishes a competitive advantage for it. Wu, Chang and Chen (2006) stated that firms seek to 
remain relevant within their dynamic business environment through diversification and adaptation as well as improvement in existing products, services, methods or processes.

\section{Adaptability}

Adaptability signifies the creative skill of a firm to swiftly respond to openings and challenges and translate same into business advantages. Thus, the tenacity to react to the needs of their clients as well as making ideal choices, as deliberate action to change established patterns of operations (Macmillan \& Tampoe, 2000).Adaptability equally applies to an organisation's structure and how it is amenable to environmental changes as captured in the firm's strategic plan. Such a structure must support the implementation of the firm's survival strategy. The expression of the capability to adapt or adjust to varying, shifting, and changing circumstances is a fundamental basis of the premeditated choice. (Kotter \& Heskett, 1992). There is a close connection between the concepts of strategy and adaptability both in terms of practice and principle. For example, strategies are conceived to enable the organisation exploit environmental opportunities and ward off threats by adjusting its operations accordingly. Both strategy and adaptability tells the firm what rivals are doing and ways to position itself and compete favourably. Furthermore strategic planning is highly related to an organisation's ability to thrive in its operating domain. Adaptability in the field of strategic planning is the application of an organisation's capability in response to environmental trends (Reeves \& Deimler, 2011). Adaptability, nonetheless, has far-reaching implications than simply formulating a strategic plan.

Robertson \& Sribar (2004), noted that responding with modifications to structural arrangement is key to a successful adaptation to the changes in the environment that influences the proper running of the firm. Organisations that are successful in adapting to the environment manifest some key characteristics: their structures have few layers of hierarchy in which groups can be formed spontaneously to accomplish set objectives that advances the realization of the firm's overall objectives; workers clearly understand organisational policies and are devoted to accomplishing shared objectives which also furthers the realization of their individual objectives; both managers and subordinates jointly generate and evaluate ideas for solving organisational problems; there is quick response to environmental changes because of the willingness and capability of its members; and there is full adoption of the principles of organisational learning theory as a means to enhancing its competitiveness (Macmillan \& Tampoe, 2000).

\section{Empirical Review}

Duke and Kamkpang (2011), studied the nexus between corporate governance and organisational performance among quoted and unquoted firms in Nigeria. In the study, the dimensions of corporate governance were board size, reliability of financial reporting, existence of code of corporate governance, separation of the office of board chairman and CEO and audit committee, while profit margin and assets measured organisational performance. Results of the regression analysis showed that both return on assets and profit margin are positively affected by the size of the board, position of the CEO, audit committee and code of corporate governance. It was recommended that there should be high standards for selecting non- executive and independent members of the board. Afolabi and Dare (2015), studied the problems and concerns of corporate governance among companies in the Nigerian banking sector. Data for the study were generated from a total of 100 respondents through questionnaire. Results of the Pearson correlation analysis revealed that inadequate oversight and accountability of the board affects the corporate governance strength of the banks and threatens their survival. The increasing level of fraud among banks is due to inadequate corporate governance principles and practices. It was recommended that a culture of whistle blowing be encouraged as well as establishing special courts for trying corporate issues.

Olannye and Anuku (2014) examined the influence of corporate governance on performance of banks in Nigeria. The results of the regression analysis showed that ethical conduct, which measured corporate governance, has significant relationship with employees' productivity. The study concluded that unethical conduct of workers create problems for individuals, groups and the company as a whole thereby impeding efficiency and success. It was recommended that management should intensify efforts at instilling standards among employees.

The link between world-wide financial crisis, corporate governance and organisational survival formed the research concern of Iwasaki (2012). The study was conducted in Russian firms through a widespread panel survey from 2005 to 2009. Board independence; the adequacy of personnel that make up the governance bodies were all positively correlated with the survival ability of the firms. It was found that independent company board also positively affect the survival prospect of the firms. Limpaphayom and Connelly (2004) studied the relationship between board characteristics and organisational performance among insurance companies in Thailand. The results indicated that board structure positively relate with profitability, while it has negative effect on risk behaviour of a firm. 


\section{Methodology}

The cross sectional survey research design was utilised for this study it is a method that gathers data at a given point in time. A total of 269 copies of questionnaire were distributed to management staff out of which 213 (79\%) were retrieved, $198(74 \%)$ copies of the questionnaire retrieved were deemed usable. The data was analyzed by the use of Spearman Rank Order Correlation Coefficient, a non-parametric statistical tool. While the hypothesis were tested for significance by the method of $\mathrm{p}$ value at 0.005 level of significance. Alpha $(\alpha)=0.05$ level of significance and followed the rule for interpretation.

\section{Hypothesis Testing}

H01: There is no significant relationship between Board Independence and Innovation.

Table 1: Relationship between Board Independence and Innovation

\begin{tabular}{|c|c|c|c|c|}
\hline & & & $\begin{array}{c}\text { Board } \\
\text { Independence }\end{array}$ & Innovation \\
\hline \multirow{8}{*}{ Spearman's rho } & \multirow{4}{*}{$\begin{array}{l}\text { Board } \\
\text { Independence }\end{array}$} & $\begin{array}{l}\text { Correlation } \\
\text { Coefficient }\end{array}$ & 1.000 & $.372^{* *}$ \\
\hline & & & & .000 \\
\hline & & Sig. (2-tailed) & & \\
\hline & & $\mathrm{N}$ & 198 & 198 \\
\hline & \multirow{4}{*}{ Innovation } & Correlation & $.372^{* *}$ & 1.000 \\
\hline & & Coefficient & & \\
\hline & & Sig. (2-tailed) & .000 & \\
\hline & & $\mathrm{N}$ & 198 & 198 \\
\hline
\end{tabular}

. Correlation is significant at the 0.05 level (2-tailed).

The result of the analysis in table 1 shows a rho value of 0.372 and $p<0.05$. This signifies that a positive and significant weak relationship exists between board independence and innovation. The null hypotheses was thus rejected.

H02: There is no significant relationship between board independence and adaptability

Table 2: Relationship between Board Independence and Adaptability

\begin{tabular}{|lll|r|r|}
\hline & & \multicolumn{1}{c|}{$\begin{array}{c}\text { Board } \\
\text { Independence }\end{array}$} & Adaptability \\
& & Correlation & 1.000 & $.868^{* *}$ \\
& Board & Coefficient &. & .000 \\
& Independence & Sig. (2-tailed) & 198 \\
Spearman's rho & & $\mathrm{N}$ & $.868^{* *}$ & 198 \\
& & Correlation & \\
& Adaptability & Coefficient & .000 & 1.000 \\
& & Sig. (2-tailed) & 198 &. \\
& & $\mathrm{~N}$ & 198 \\
\hline
\end{tabular}

${ }^{* *}$. Correlation is significant at the 0.05 level (2-tailed).

The result of the analysis in table 2 indicates $r h o=0.868, \mathrm{p}<0.05$. This implies that board independence has a significant and strong positive correlation with adaptability. The null hypothesis was thus rejected. 
$\mathbf{H 0}_{3}$ : There is no significant relationship between board supervision and innovation.

Table 3: Relationship between Board Supervision and Innovation

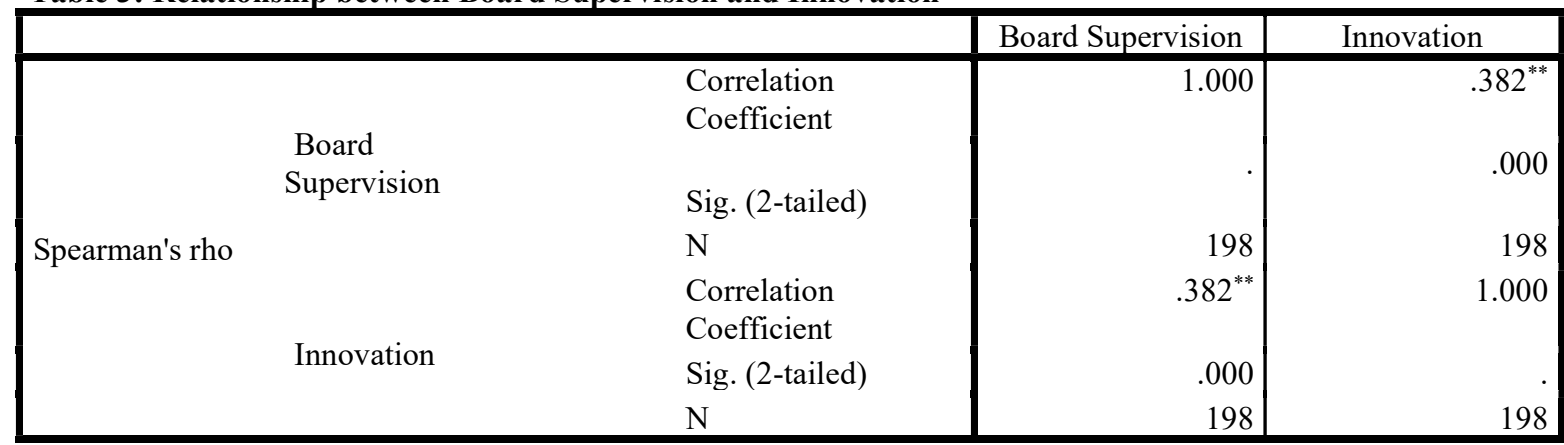

. Correlation is significant at the 0.05 level (2-tailed).

The result of the analysis in table 3 shows $r h o=0.382$ and $p<0.05$. This indicates that relationship between board supervision and innovation in manufacturing firms in Port Harcourt is positive and significant. The null hypothesis was thus rejected.

H04: There is no significant relationship between board supervision and innovation

Table 4: Relationship between Board Supervision and Innovation

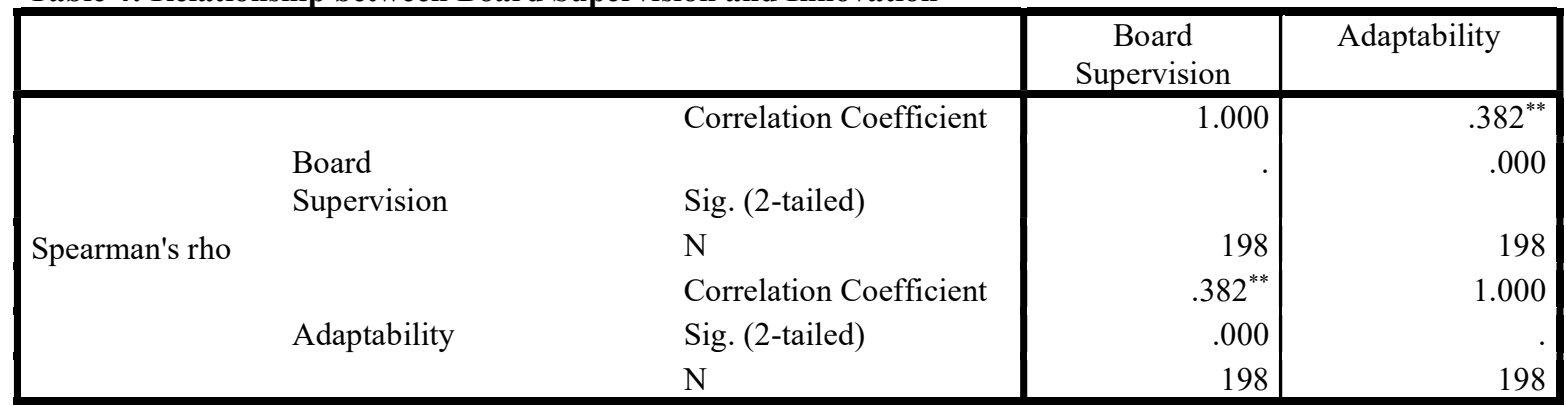

. Correlation is significant at the 0.05 level (2-tailed)

The result of the analysis shows $\mathrm{p}<0.05$ ) and $\mathrm{rho}=0.382$. This implies that the relationship between board supervision and adaptability is significant, positive but a weak one. The null hypothesis was thus rejected.

\section{Discussion of Findings}

Findings from the test of hypotheses revealed that a positive and significant relationship exists between board independence and measures of organisational survival (innovation and adaptability); as well as between board supervision and the measures of organisational survival (innovation and adaptability). This result corroborates with Iwasaki (2012) who found that board independence positively and significantly influences the survival of organisations. The findings of Dabor, Isiavwe and Ajagbe (2015); Elsayed (2007) also found support from this study as they established that the independence and supervision of the board strongly impacts the survival ability of organisations especially in terms of innovation and adaptability. In addition, this study strengthened the findings of Rechner and Dalton (1991) where they reported that corporate governance equips the directors and managers with professional know-how for better management and overseeing of the performance of a firm.

\section{Conclusion}

Corporate governance seeks the protection of the interest of all who have a stake in an organisation. The findings of this study shows that corporate governance can enhance a company's performance, and also its survival in the long run. Corporate governance solidifies the core principles necessary for a robust business firm in the globalized and highly competitive business environment. Among other things, this study reveals that board independence and board supervision correlates with adaptability and innovativeness significantly. The independence of the board provides a company with diverse and interdependent-minded ideas that can unlock opportunities for creativity, innovation and resourcefulness. Perhaps the greatest indicator of a firm's long-term survival is its capacity to adjust, within reasonable time, to environmental changes. This ability is, nonetheless, affected by the quality of members that sit on the company's board. Additionally, to be successful in driving the 
survival of a company, corporate governance mechanisms have to operate within an appropriate structure. A firm's structural framework should provide support to enhance execution of board-level decisions and policies for effective and efficient acquisition, allocation and accountability of resources.

\section{Recommendations}

Arising from the findings and conclusion of the study, the following recommendations were made;

1. Owners and managers should ensure that board members supervise the operations of the firm as this will ensure operational excellence and enhance survival.

2. Manufacturing firms in Port Harcourt should ensure that their board are independent to enhance their level of adaptability to changing business environment.

3. Owners and managers of manufacturing firms should ensure appropriate balance between executive and non-executive directors on their board. This will ensure symmetry, both in the variety in opinion and an alignment of policies formulated and the technicalities of their execution.

4. Greater priority should be the quality of board members rather than the numerical strength of the board. A small board with members who have a great wealth of knowledge and connections makes better decisions, and at lower cost to the firm, than one whose strength is only in its number.

5. The Board of management team should not be above evaluation. It should be monitored and assessed by independent external auditors. Monitoring helps to entrench transparency, accountability and trust among organisational stakeholders.

\section{References}

Abid, G., Khan, B., Rafiq, Z., \& Ahmed, A. (2014). Theoretical perspectives of corporate governance. Bulletin of Business and Economics, 3(4), 166-175.

Adams, R. \& Mehran, H. (2003) Is corporate governance different for bank holding companies? Economic Policy Review - Federal Reserve Bank of New York, 9(1), 123-142.

Afolabi, A. \& Dare, A. M. (2015). Corporate governance in the Nigerian banking sector: Issues and challenges. European Centre for Research Training and Development, UK, 3(5), 64-89.

Alli, F. (2017). 2016 in review: manufacturing sector groans under recession weight. Vanguard. Retrieved from https://www.vanguardngr.comI2O17/01/2016-review-manufacturing-sector-groans-recession-weight!

Anyanwu, S. A. C., \& Agwor, T. C. (2015). Impact of mergers and acquisitions on the performance of manufacturing firms in Nigeria. African Research Review, 9(2), 156-165.

Boyd, B. K. (1995). CEO duality and firm performance: A contingency model. Strategic Management Journal, 16(4), 301-312.

Buthala, H. (2008). Board characteristics and firm performance: Evidence from New Zealand. (PhD Thesis Submitted to Auckland University of Technology, Auckland, New Zealand).

Chambers, N., Harvey, G. Mannion, R., Bond, J. \& Marshall, J. (2013). Towards a framework for enhancing the performance of NHS boards: A synthesis of the evidence about board governance, board effectiveness and board development. Retrieved from www.ncbi.nlm.nih.gov.

Chancharat, S., \& Chancharat, N. (2013).Corporate governance and company survival. Silpakorn University Journal of Social Sciences, Humanities, and Arts. 13(1), 33-62.

Connelly, J. T. \& Limpaphayom, P. (2004). Board characteristics and firm performance: Evidence from the life insurance industry in Thailand. Chulalongorn. Journal of Economics, 16(2): 101-124.

Dabor, A.O., Isiavwe, D.T., \& Ajagbe, M.A. (2015). Impact of corporate governance on firms' performance. International Journal of Economics. Commerce and Management United Kingdom. 3(6).

Daily, C., Dalton, D.R., \& Cannella, A.A. (2003). Corporate governance: Decades of dialogue and data, The Academy of Management Review, 28, 3, 371-382.

Darroch, J. (2005). Knowledge management, innovation and firm performance. Journal of Knowledge Management, 9(3), 101-115.

Dharwardkar, R., George, G. \& Brandes, P. (2000). Privatization in emerging economies: An agency perspective. Academy of Management Review, 25(3), 650-669.

Donaldson, L. (1990). The ethereal hand: Organisational economics and management theory. Academy of Management Review, 15(3), 369-382.

Duke, J., \& Kankpang, K. (2011). Linking corporate governance with organisational performance: New Insights from Nigeria. Global Journal of Management and Business Research, 11(12), 47-57.

Elsayed, K. (2007). Does CEO duality really affect corporate performance? Corporate governance: An International Review, 15(6), 1203-1214.

Enofe, A. \& Isiavwe, D. (2012). Corporate disclosure and governance in the Nigerian banking sector: An empirical evaluation. The International Journal's Research Journal of Social Science \& Management. Singapore. 
Iwasaki, I. (2012). Global financial crisis, corporate governance, and firm survival: The Russian experience. Russian Research Centre. The Institute of Economic Research Hitotsubashi University Kunitachi, Tokyo, Japan.

Khanka, s.S. (2008). Organisational behaviour. New Delhi: Schand \& Company.

Kotter, J.P., \& Heskett, J.L. (1992). Corporate culture and performance. New York: The Free Press.

Lamberto, A.P. \& Rath, S. (2008). The survival of initial public offerings in Australia: Curtin University of Technology.

Macmillan, H., \& Tampoe, M. (2000). Strategic management. Oxford: Oxford University Press.

Matai, D.K. (2011). What is the key to survival in a constantly changing environment? Retrieved from www.businessinsider.com/what-os-the-key-to-survival-in-a-constantly-changing-environment-2011$3 ? r-U S \& I R=T \& I R=T$.

Maher, M., \& Anderson, T. (1999). Corporate governance: Effects on firm performance and economic growth. Retrieved June 5, 2017, from www.oecd.or/sti/ind/2090569.pdf.

Nigerian manufacturers lament: 272 firms shut, 20\% capacity utilisation, other challenges in 2016. (2017, January 10). Premium Times. Retrieved July 17, 2017, from www.premiumtimesng.com/news/hearlines/220035-nigerian-manufacturers-lament-272-firms-shut-20capacity-utilisation-challenges-2016.html.

Odiwo, W.O., Chukwuma, C.S., \& Kifordu, A.A. (2016). The impact of corporate governance on the performance of manufacturing firms in Nigeria. International Journal of Science and Research, 5(9), 924-933.

OECD (2001). Corporate governance and national development. Technical Papers No. 180. Organisation for Economic Co-operation and Development, Paris (46).

Olannye, A.P. \& Anuku, D. (2014). Corporate governance and organisational performance in the Nigerian banking industry. Journal of Emerging Trends in Economics and Management Sciences (JETEMS), 5(6), 525-531.

Omolade, O.O. \& Tony, O.A. (2014). Effect of corporate governance on the survival and survival of banks in Nigeria. American Journal of Engineering Research (AJER).

Oyebode, A. (2009). The imperative of corporate governance in Nigeria. Retrieved from http://www.ngierianwillagesquare.com/articles/akin-oyebode.

Pass, C. (2004). Corporate governance and the role of non-executive directors in large UK companies: An empirical study. Corporate governance, 4(2): 52-63.

Pfeffer, J., \& Salancik, G. (1978). The external control of organisations: a resource dependence perspective. New York: Harper and Row.

Prajogo, D.I., \& Sohal, A.S. (2001). TQM and innovation: A literature review and research framework, Technovation, 21, pp. 539-558. PVT Ltd.

Rechner, P.L. \& Dalton, D.R. (1991). CEO duality and organisational performance: A longitudinal analysis. Strategic Management Journal. 12(2): 155-160.

Reeves, M., \& Deimler, M. (2011). Adaptability: The new competitive advantage. Harvard Business Review, 89(7), 135-141.

Robertson, B., \& Sribar, V. (2004). The adaptive enterprise it infrastructure strategies to manage change and enable growth. It Best Practices Series. International Press.

Roper, J. (2012). Environmental risk, survival discourses and public relations. Public Relations Inquiry, 1(1), 69-87.

Sarbah, A. \& Xiao, W. (2015). Good corporate governance structures: A must for family businesses. School of Management \& Economics, University of Electronic Science \& Technology of China (UESTC) Chengdu, China.

SSetia, S. \& Soni, M. (2013). Survival in manufacturing. The technology landscape, Tata Consultancy Services Limited, White Paper.

Sharma, S., \& Ruud, A. (2003). On the path to sustainability: Integrating social dimensions into the research and practice of environmental management. Business Strategy and the Environment, 12(4), 205-214.

Weir, C. \& Laing, D. (2001). Governance structures, director independence and corporate performance in the UK. European Business Review, 13(2): 86-94. 